\title{
Read any good books lately?
}

\author{
T. Jock Murray*
}

"To study the phenomenon of disease without books is to sail an uncharted sea, while to study books without patients is not to go to sea at all"

Sir William Osler

While emphasizing the place of books and experience with patients in medical education, it was not only medical texts that Osler felt students should read and know. He had a recommended list of bedside books for medical students (Table 1).

In some cases Osler, the most famous of McGill professors, was recommending a body of work rather than a book, and although he was not explicit in what we should take from these writings as future physicians, he clearly felt that these writings contained important teachings and knowledge that would make a student a better physician. Osler himself was a great bibliophile, and his writings are sprinkled with quotations and lessons from an amazingly wide range of classical, fictional and medical literature (1). He donated his great collection of medical and related works to McGill, which formed the basis of the Osler Library in the McIntyre Medical Sciences Building.

A current medical student would understandably regard many of the works on the list as outside their experience and would expect more familiar books on a modern list. If so, what books? What books would students now suggest for a modern list?

Updating Osler's bedside library list has been attempted a number of times $(2,3,4)$ and most recently by a group from the American Osler society (5). Dr. Francis Neelon, then President of the AOS, assisted by Dr. Robert Rakel and Dr. Herbert Swick, canvassed members to see if a new list could be developed. It proved a difficult challenge. The Society members were asked how many of Osler's suggestions they had read,

*To whom correspondence should be addressed:

Dr. T. Jock Murray

Dalhousie University

Medical Humanities Office

Sir Charles Tupper Building

B3H $4 \mathrm{H} 7$

Email: Jock.murray@dal.ca
Osler's bedside table Library for Medical Students

1. Old and New Testament

2. The works of Shakespeare

3. The works of Montaigne

4. Plutarch's Lives

5. Meditations by Marcus Aurelius

6. Breakfast Table Series by Oliver Wendell Holmes

7. Discourses of Epictetus

8. Religio Medici by Sir Thomas Brown

9. Don Quixote by Miguel Cervantes

10. The works of Emerson

Table 1

and then they were asked to make recommendations for a new list (5). There were 19 responses. Perhaps the nature of Society members, who have a high interest in history, literature and the humanities, and their devotion to Sir William Osler, accounts for the high response to

Some suggestions from members of the American Osler Society (Neelon)

1. Shakespeare

2. Old and New Testament

3. Don Quixote by Cervantes

4. Religio Medici by Sir Thomas Browne

5. The Doctor Stories by William Carlos Williams

6. William Osler: a Life in Medicine by Michael Bliss

7. Life of Johnson by James Boswell

8. Man's Search for Meaning by Victor Frankl

9. Collected Essays by Sir William Osler

10. The Prince by Machiavelli

11. The Story of Civilization by Will and Ariel Durant

12. The historical works of Winston Churchill

Table 2 
the reading of Osler's list (Shakespeare 95\%; Old and New Testament 84\%; Don Quixote 68\%; Oliver Wendell Holmes 53\%; Religio Medici 42\%; Emerson 42\%; Marcus Aurelius 37\%; Plutarch's Lives 32\%; Montaigne 21\%; Epictetus 0\%).

More interesting is the list of 124 books put forward for a new list by the 19 respondents and some of those with multiple recommendations are appended (Table 2). Some from Osler's original list were among those recommended by more than one person, with top of the list going to Shakespeare, the Old and New Testament, Don Quixote by Cervantes, and Religio Medici by Sir Thomas Browne. Others that were recommended more than once by Society members were various anthologies of poetry, The Doctor Stories by William Carlos Williams, the biography of the great physician, William Osler: a Life in Medicine by Michael Bliss, Life of Johnson by James Boswell, Man's Search for Meaning by Viktor Frank1, Osler's Collected Essays, Machiavelli's The Prince, Will and Ariel Durant's The Story of Civilization, and the historical works of Winston Churchill (Table 2).

Interesting as these books may be, they come from mostly senior and often retired physicians, and although I now am a member of this graying group, I suspect my generation may not be the best to suggest a bedside list for medical students. I wonder if the students themselves couldn't create a relevant list that would resound with their peers.

In my experience, medical students prefer books written by physicians (6). Table 3 has a partial list of physician writers, and there are many other writers who write about medicine.

Students today have more extensive and diverse backgrounds, education and experiences than ever before. It would be enlightening to see a list compiled by medical students. Would there be graphic novels, science fiction or fantasy, pop culture novels? Should the books be inspirational, empowering, educational or just interesting? Would there be podcasts, blogs, magazines? (My own list submitted to the AOS included the Times Literary Supplement and Literary Review which I find highly informative on many subjects and ideas).

\begin{tabular}{|ll|}
\hline Some Physicians writers & \\
Danny Abse & Michael Crichton \\
Harold Klawans & Walker Percy \\
John Aiken & Erasmus Darwin \\
Michael LaCombe & Francois Rabalais \\
Mary Aikenside & Paul DeKruif \\
John Locke & Peter Mark Roget \\
Richard Asher & Sir Arthur Conan Doyle \\
Saint Luke & Oliver Sacks \\
Thomas Beddoes & William Drummond \\
Somerset Maugham & Richard Selzer \\
Robert Bridges & Macdonald Critchley \\
Sir Andrew Macphail & Frank Slaughter \\
Mikhail Bulgakov & Jacques Feron \\
John MacCrae & Tobias Smollett \\
Thomas Campion & Sir Samuel Garth \\
Jonathan Miller & John Stone \\
Anton Checkov & Oliver Gogarty \\
Silas Weir Mitchell & Lewis Thomas \\
Clif Cleaveland & Oliver Goldsmith \\
Axel Munthe & Abraham Verghese \\
Robert Coles & Oliver Wendell Holmes \\
Sir William Osler & William Carlos Williams \\
Jack Coulehan & Perri Klass \\
Wilder Penfield & Thomas Young \\
& \\
\hline \hline
\end{tabular}

Table 3

\section{REFERENCES}

1. Fye B. William Osler's Bibliomania. Osler Library Newsletter 2002;98:1-8

2. Reynolds RC. Osler's bedside library revisited. Pharos 1965;48:34-36

3. Rakel RE. Modern version of Osler's bedside library. Perspect Biol Med 1988;31:577-585

4. Pai SA, Gusahani RD. Osler's bedside library revisited - books for the 21st century. BMJ 2005;331:1482

5. Neelon FA. Osler's bedside library: a survey and a proposal. Presidential message. The Oslerian 2007;8:1-2

6. Murray TJ. Physicians as writers. Presidential message, The Oslerian 2006;7: 1-2

T. Jock Murray is the former Dean of Dalhousie Medical School and Professor of Medicine (Neurology) and founding director of the Dalhousie Multiple Sclerosis Research Unit. He held the first Chair of Medical Humanities at Dalhousie. He is a past President of the Association of Canadian Medical Colleges and former Chairman of the Canadian Medical Forum. He was the founder of the Dalhousie Society for the History of Medicine, past President of the Canadian Society for the History of Medicine and the President-Elect of the American Osler Society.

Dr. Murray has over 225 medical publications, 9 books, 43 text book chapters, and has held 91 funded research grants. Recent books have been Medicine in Quotations (with Edward Huth), The Quotable Osler (with Mark Silverman and Charles Bryan), and Multiple Sclerosis: The History of a Disease. 